\title{
丘陵地の植生構造が繁殖期の鳥類に及ぼす影響について
}

\section{The Influence of Vegetation Structure on Avifauna at Breeding Season in Hills}

\author{
森田健吾* 葉山嘉一 ${ }^{*}$ \\ Kengo MORITA Yoshikazu HAYAMA
}

\begin{abstract}
摘要 : 都市近郊における樹林地での管理手法が求められている現在, 樹林の生息空間構造の関係を把 握することは重要である。本研究は丘陵地の公園において, 樹林構造の相運による鳥相の変化を把握 し、管理計画策定のための基礎資料を得ることを目的とした。調查は神奈川県立七沢森林公園で異な るタイプの樹林 12 ヶ所を対象に, 繁殖期の 4 月から 6 月に鳥類と植生の調查を行い検討した。その 結果, 個々の種によって選好する環境が異なり，樹林タイプごとに鳥類の種組成が異なること，草本 層の植被率が鳥類の個体数增加や柾林性鳥類の生息に影響を及ぼしていると，鳥種の多樣化に複数 の要素が影響する可能性と繁殖期の低木層密度の重要性が示唆された。
\end{abstract}

\section{1.はじめに}

都市近郊の樹林地は過去には主に農用林としての維持管理が進 められていた。しかし 1960 年以降のエネルギー需要や農業生産 構造の変質により農用林の経済的価値が喪失し, 放棄された樹林 地が増加した。近年, こうした樹林に対して生態的価值が評価さ れ，その管理手法の確立が求められるようになった。特に都市公 園においては雑木林を中心とする樹林を生物生息空間として位置 づけ，保全を図ることが進められてきた。しかし生態的機能を持っ た樹林としていかなる管理を進めていくかについては，いまだ模 索段階であり, どの様な樹林を維持するかを検討するために, 小 動物の生態特性と樹林の空間構造との関係を明らかにすることは 非常に重要であると考えられる。

鳥類に関してはこれまでも樹林地との関係について多くの研究 が行われてきた。村井ら(1988)は鳥類の生息には林内の空間が十 分に大きいこと, また階層構造の発達が重要であることを明らか にしている ${ }^{1)}$ 。葉山 $(1994,1996)$ は都市公園内において人為の影 響が強い樹林の中で落葉広葉樹林の重要性, 低木の繁茂状態が鳥 類の種多様性に影響を及ぼすことを示唆している233)。また一ノ瀬 ら(1994,1996,1999)の一連の研究では鳥類の種数・個体数に対し て, 生息地の面積, 植生構造の複雑さ, 特に低木層の植生構造の 複雑さが影響しており，一つの樹林地内に様々な林分が存在する ことが重要であると示唆している ${ }^{455663}$ 。加藤 (1996) は低木層の発 達については植被率が $40 \%$ 以上になると種数は増加しなくなる 可能性を述べている7”。これらの研究で鳥類に影響を与える樹林 地構造の要因の一部が明らかにされ, 階層構造の複雑さが影響し ていることが多く報告されている。しかし階層構造や樹林を構成 する要素の詳細についての研究は十分に蓄積されておらず, 特に 植生構造が鳥類に与える影響に関しての具体的な研究は少ない。 樹林地の植生構造全体の目標を決定する植生計画やその具体化を 図る植生管理計画の指針を得るためには，階層構造の詳細な検討 や管理のための樹林規模単位や管理ローテーションの問題, ある いは管理時期の問題など解決すべき事項が多く残されている。そ のためにより具体的な研究を蓄積していくことは重要である。

そこで本研究では, 丘陵地の公園において樹林構造の相違によ る繁殖期の鳥類に及ぼす影響を把握し, 定量的手法を用い, 個々 の植生構造が鳥に対してどのような影響を与えているかを明らか にし，具体的な樹林管理手法に対する指針を検討するための基礎
資料を得ることを目的として行った。

\section{2. 研究概要}

\section{(1) 調査対象地}

調查は神奈川県厚木市に位置する，県立七沢森林公園において 行った（図一 1 )。当公園は丹沢山塊の東部丘陵地に位置し，供 用面積は $64.6 \mathrm{ha}$ である。標高は $60 \sim 190 \mathrm{~m}$ であり，地形は南北 に長く延びた尾根とその斜面で構成されており，クヌギ・コナラ・ イヌシデ・エンコウカエデを中心とする夏緑広葉樹林やスギーヒ ノキ植林が分布している。公園内ではノウサギやホンドリス, 二 ホンジカ，二ホンザルなどあ生息しており，自然環境の保全を主 要な目的とした都市公園として質の高い自然が維持されている。 また平成 7 年 2 月から市民参加による雑木林管理が行われている。 公園の管理については部分的にボランティアが参加するものの,

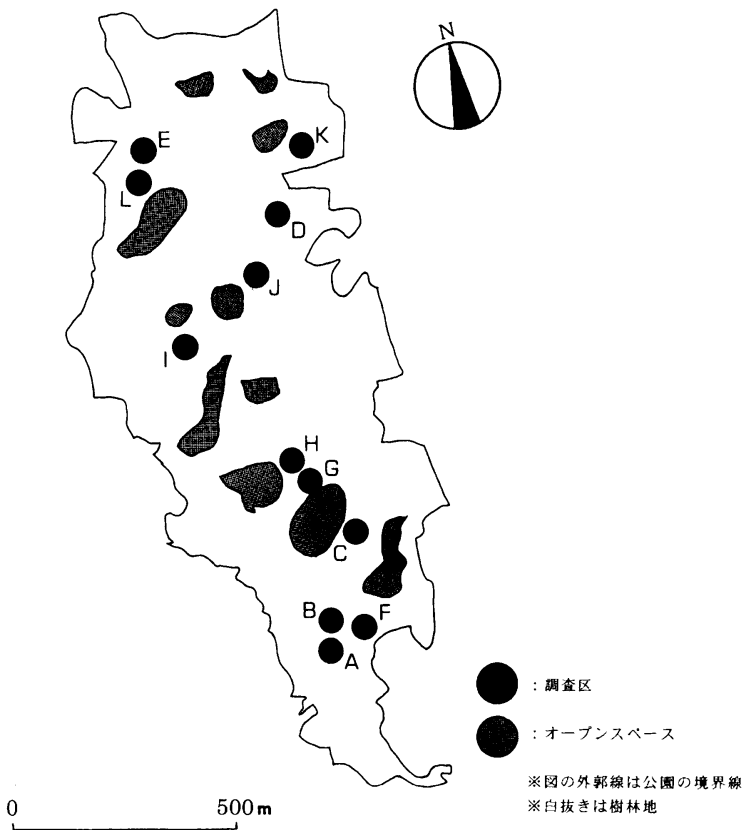

図-1 調查対象地

•日本大学生物資源科学部 
主要部は県の土木事務所が行っている。公園に隣接して県立自然 保護センター, 厚木森の里ニュータウンなどがあり, さらに樹林 地は丹沢山塊に連なっている。

調查地区は階層構造の違いによる植生相観の差異により 12 地 点を選出した。この地区に半径 $25 \mathrm{~m}$ の調査区を設定し, 鳥類調 査と植生調查を行った。調査範囲は樹林内ということもあり, ま た点センサス法を用いるため目視が可能な半径 $25 \mathrm{~m}$ とした。以 下それぞれの調查区を $\mathrm{A} \sim \mathrm{L}$ 区と称する。

\section{(2) 鳥類調查}

鳥類調査は鳥類の繁殖期に当たる 1999 年 4 月 14 日から 6 月 22 日の合計 14 日間で行った。調査は 12 地点を 6 地点ずっ 2 日間に わけて行い, 1 地点当たりでは 7 日間実施した。調査時間は日の 出時間から 1 時間後に開始し, 6 地点の調査が終了するまでとし, 遅くとも午前 9 時には終了した。なお, 調查時間のずれによる出 現率の変化を考慮して, 調査毎に開始地点を変更して行った。

調査方法は点センサス法を用い, 半径 $25 \mathrm{~m}$ 内で確認できる種 を全て記録した。大迫 $(1989)^{8)}$ によると点センサス法は一定時間 静止して観察を行うため調查精度が高い方法とされている。観察 に際しては必要に応じて調査区内を移動して記録した。ただし, 明らかに同一個体と考えられる個体，上空通過の個体については 記録から除外した。調查項目については種・個体数・確認方法・ 行動等を記録し，時間については連続して 10 分間新たな種が記 録されなくなるまで調查を継続する手法を採用した。1998 年に 予備調查として 5 地区を対象に調查時間を 30 分に設定して行っ た。今回の手法は一定時間(30 分)を設定して実施する手法と比 較するとやや効率的であり，また得られたデー夕に大きな差は認 められなかった。調查時間は 17 分から 30 分程度であった。また 天候が雨の日を除いて行った。

\section{(3) 植生調查}

植生の種組成・階層構造を把握するため, 鳥類調査を行った 12 所の調査区で 1999 年 9 月に植生調查と毎木調査を行った。 調査区内に $100 \mathrm{~m}^{2}$ のコドラートを各 1 ヶ所設置し, 出現した全て の種について被度, 群度を記録し, また階層ごとの優占種と植被 率を記録した。階層は高木層, 亜高木層, 低木層, 草本層の 4 層 に分けた。さらに毎木調查を行い種毎の本数, 樹木の高さ, 樹林 密度について記録した。なお樹林密度については今回, 各地区の 樹木の胸高断面積の合計をコドラート面積内に占める割合に換算 して樹木密度を求め, それを樹林密度と称した。通常は $0.5 \%$ 前 後でうっぺいした樹林とされている ${ }^{9)} 。$

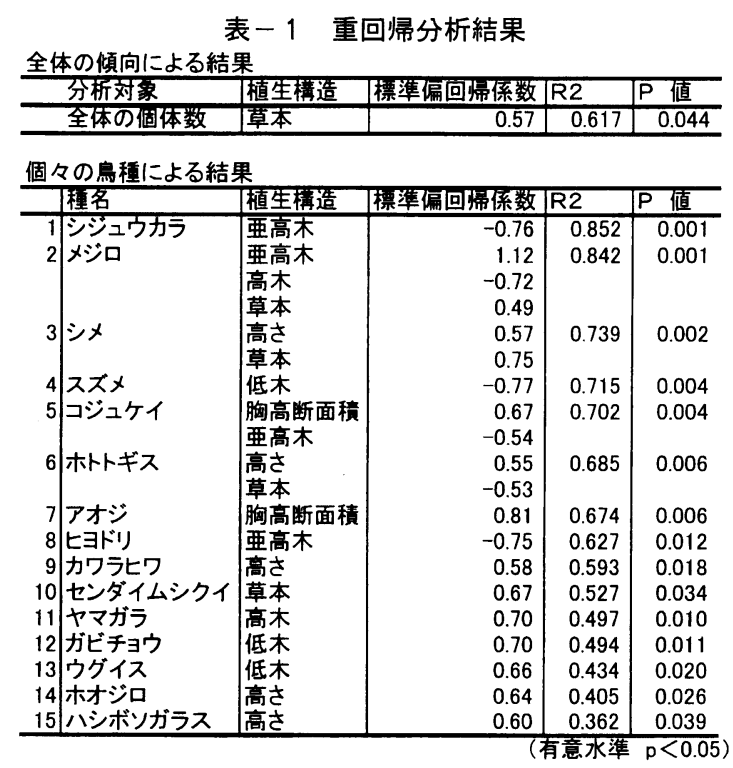

\section{3. 結果}

\section{(1) 重回帰分析の結果}

繁殖期において全 7 回の調查を実施し, 30 種 1340 個体が記録 された。分析には, 全体の傾向を検討するために全種全個体を対 象とし, さらに詳細な検討のために偶然の出現と考えられる種や 2 地点以下にしか出現しなかった種を除いた 22 種を対象にした。 分析手法は鳥と植生構造についての関係を把握するため, 多变量 解析の 1 手法である重回帰分析を用いた。植生構造の要素につい ては, 植生調査の結果から樹林の高さ, 密度, 各階層の植被率を 取りあげた。それらの分析結果を表一 1 に示す。

まず始めに全体の傾向を見るために鳥類全体の種数と個体数を 目的変数, 各樹林の植生構造を説明变数とし, 増減法による变数 選択をして分析を行った。その結果, 個体数と草本層の植被率の 間に有意な相関が認められた。種数やその他の植生構造について は有意な相関が得られなかった。草本層と個体数の関係について は, 草本層の植被率が増加すると個体数が増加するという結果が 得られた。

次に対象 22 種について種毎の個体数を目的変数とし，説明変 数である樹林の要素を増減法によって選択して重回帰分析を行っ た。その結果, 有意な相関が認められかつ寄与率 ( R 2 ) が 0.5 以 上だった種は, シジュウカラ・メジロ・シメ・スズメ・コジュケ イ・ホトトギス・アオジ・ヒヨドリ・カワラヒワ・センダイムシ クイの 10 種であった。これら 10 種に相関があった植生の要素之 しては, 樹林の高さはカワラヒワ・シメ・ホトトギス，高木層の 植被率はメジロ，亜高木層の植被率はシジュウカラ・メジロ・七 ヨドリ・コジュケイ，低木層の植被率はスズメ，草本層の植被率 はメジロ・センダイムシクイ・シメ・ホトトギス, 樹林密度はア オジ・コジュケイという結果が得られた。相関関係にある要素の 数は種によって異なり，1つだけの要素に相関が認められたのは 6 種で, シジュウカラ・スズメ・アオジ・ヒヨドリ・カワラヒワ・ センダイムシクイである。2つの要素ではシメ・コジュケイ・ホ トトギスの 3 種で， 3 つの要素に相関が認められたのはメジロ 1 種であった。しかしこれらの要素は全てがプラスの関係にあるわ けではなく，メジロに対する高木層の植被率，シジュウカラ・ヒ ヨドリ・コジュケイに対しての亜高木層の植被率，スズメに対す る低木層，ホトトギスに対する草本層の植被率はマイナスに働く 要因という結果が得られた。また，種全体を対象とした分析で個 体数と相関関係にあった草本層の植被率については, メジロ・セ ンダイムシクイ・シメの 3 種がプラスに働いていた。以上のよう に, 種ごとに相関関係にある要素が異なっていることが分かった。 (2) クラスター分析の結果

調查を行った 12 箇所の調査地点を，樹林の各階層の植被率と

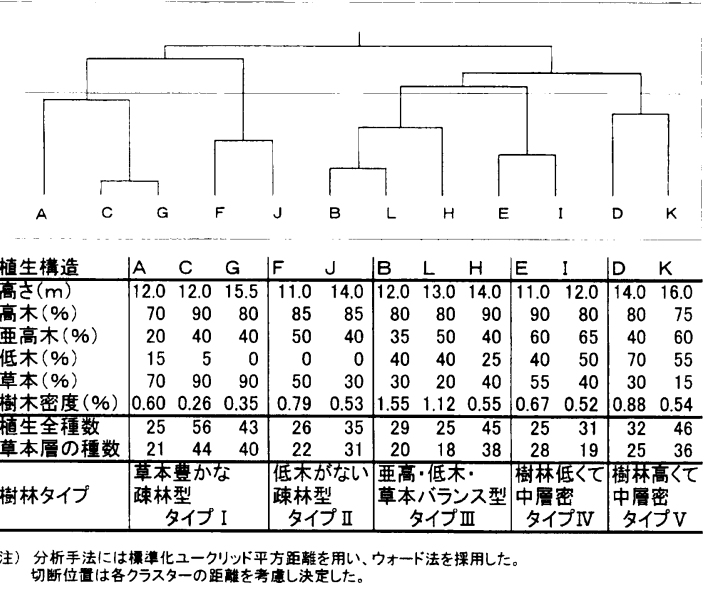

図ー2 クラスター分析結果 
高さを元にクラスター分析によるタイプ分けを行った。本研究の 手法は解釉しやすいクラスターを形成することが多いと判断され る標準化ユークリッド平方距離を用いたウォード法を採用した。 デンドログラムの切断位置は一般的な基準が無いため, 恣意性が 高くなるが, 各クラスターの距離を考慮して 5 つのタイプに分類 し，それぞれをタイプ I 〜 V とした(図－2）。タイプ I は草本が 豊かな疎林型で, 草本層の植被率が $70 \%$ 以上あり, 亜高木層・ 低木層の植被率が低い夕イプである。これには A・C・G区の 3 区が入った。タイプII は低木層が無い疎林型である。このタイプ は低木層が無く，亜高木層と草本層の植被率が 30 50\%である。

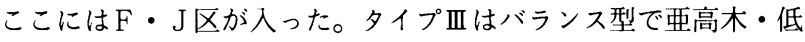
木・草本各層の植被率が 25 50\%でほぼ均等に覆っている。こ こには B・L・H区が入った。タイプIVは中層が密だが高さが低 い夕イプで, 亜高木・低木・草本各層の植被率はバランス型より あ密であるが, タイプ V と比べると樹林の高さが低い。タイプ V は樹林の高さがあり, 亜高木と低木が密な夕イプである。この夕 イプは中層が発達しているため, 草本層の植被率は低く, 高さの ある樹林である。タイプIVには E・I 区が入り，タイプVにD・ $\mathrm{K}$ 区が入った。以上のタイプ区分を概観すると I から Vへ向かう ほど疎生林から密生林へ近づくことになる。

\section{（3）各樹林タイプごとの種組成について}

重回帰分析と同じく，22 種を対象に検討した（表一 2 )。その結 果, 出現個体数に偏りが認められた種は, シジュウカラ・キビ夕 キ・アオジ・スズメ・シメ・ヤブサメ・ウグイス・ホトトギス・ ガビチョウ・ハシボソガラスの10種であった。その他の種について は個体数に大きな差はなく, また各夕イプごとに出現し，偏りは 認められなかった。差が認められた10種については, スズメは夕イ プI・II, シメは夕イプIに多く, 比較的蹯生林に多く出現して いた。ヤブサメ・ウグイス・ホトトギス・ガビチョウ・ハシボソ ガラスは夕イプIII・IV・Vに多く, 密生林で出現していた。また キビタキはタイプVだけには出現していなかった。シジュウカラ は夕イプIVおよびタイプIIIの L 区とタイプ VのK区で個体数が少 なかった。アオジはタイプIIIのB区と L区に個体数が偏っていた。

統計上植生構造との間に有意な相関が得られ, 出現傾向に偏り が認められた種はシジュウカラ・シメ・スズメ・ホトトギス・ア オジの 5 種であった。また相関が得られなかったが出現傾向に偏 りが認められた種は, ウグイス・キビタキ・ガビチョウ・ヤブサ メ・ハシボソガラスの 5 種であった。

対象種 22 種について種数・個体数を調査区ごとに比較してみ ると, $\mathrm{D}$ ・ $\mathrm{K}$ 区が 19 種・18 種と他の地区に比べて種数が多かっ た。また個体数については特にタイプ I のC区とG区が 140 羽以 上と多かった。

\section{4. 考察}

\section{（1）植生構造の相違と鳥類相の関係}

全体の傾向として有意な相関が得られたのは, 出現個体数に対 する草本層の植被率であった。これは草本層の植被率が増加する と個体数が増加する可能性があるということである。鳥類を樹林 性と樹林を利用するが主に林縁部や疎生林を好む種（これを疎林 性と称する）に分けて検討した場合も，樹林性・疎林性ともに草 本層の豊かな $\mathrm{A} ・ \mathrm{C} ・ \mathrm{G}$ 区で個体数が多く確認された。この関係 については鳥の採食行動之関連するものと考えられる。A・C・ $\mathrm{G}$ 区, 特に C・G区では植生調查の結果から草本層の種数が 40 種・4 4 種（平均 42 種）であるのに対し，他の地区では 18 種か ら 38 種（平均 26 種）である (図一2)。由井(1988)はギャップ や林縁部などの日当たりの良い場所では, 生物の生産活動が盛ん であり昆虫量や果実量などが多くなるとしている 草本層の植生が豊かである C区と $\mathrm{G}$ 区は, 林縁部に位置し低木層
表 -2 鳥類の種組成

\begin{tabular}{|c|c|c|c|c|c|c|c|c|c|c|c|c|}
\hline & \multicolumn{3}{|c|}{ タイプI } & \multirow{2}{*}{\multicolumn{2}{|c|}{ 多プII }} & \multicolumn{3}{|c|}{ 多イブIII } & \multicolumn{2}{|c|}{ S1プN } & \multicolumn{2}{|c|}{ 夕イプV } \\
\hline 理名 & A & $\mathrm{C}$ & G & & & $B$ & $L$ & $\mathrm{H}$ & $E$ & $\frac{1}{1}$ & & \\
\hline Eझाग & 35 & 46 & 45 & 29 & 39 & 31 & 26 & 24 & 17 & $\overline{24}$ & 34 & 26 \\
\hline メジロ & 13 & 14 & 18 & 16 & 11 & 13 & 14 & 9 & 16 & 17 & 12 & 20 \\
\hline エナカ & 11 & 16 & 8 & 13 & 15 & 7 & 9 & 19 & 6 & 27 & 25 & 14 \\
\hline シジュウカラ & 12 & 13 & 12 & 7 & 10 & 9 & 2 & 12 & 2 & 3 & 8 & 3 \\
\hline ヤマガラ & 4 & 1 & 4 & 7 & . & 2 & 5 & 6 & 10 & 5 & 9 & 2 \\
\hline コゲラ & 11 & 8 & 13 & 8 & 4 & 7 & 5 & - & 7 & 10 & 12 & 7 \\
\hline イカ & 2 & 1 & 6 & - & 4 & 4 & 3 & 3 & 2 & 3 & 2 & 2 \\
\hline シx & 6 & 8 & 11 & - & 1 & - & - & 9 & 1 & 3 & 2 & 4 \\
\hline グイス & 1 & - & 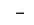 & 3 & 1 & 6 & 1 & 5 & - & 7 & 6 & 7 \\
\hline キビタキ & 3 & 1 & 1 & 1 & 1 & 2 & 4 & - & 1 & 1 & - & \\
\hline アオジ & 1 & 1 & - & 2 & - & 4 & 3 & - & 1 & - & - & 2 \\
\hline アオゲラ & _ & 2 & - & 1 & - & - & 2 & 2 & 1 & - & 1 & 1 \\
\hline ガビチョウ & - & 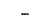 & - & 1 & - & 1 & - & - & 1 & 2 & 2 & 1 \\
\hline ヤブサ & - & - & - & & 1 & - & 3 & 2 & - & 1 & 1 & - \\
\hline コジュイイ & 2 & - & - & - & - & 2 & 1 & 1 & - & - & 1 & - \\
\hline センダイムシクイ & - & 1 & 2 & 1 & - & - & - & 1 & - & - & 1 & \\
\hline ホトトギス & - & - & - & - & - & - & 1 & 1 & - & - & 1 & 2 \\
\hline アオ八ト & - & - & - & 1 & - & - & - & 1 & - & - & - & - \\
\hline & & - & - & - & , & - & - & 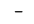 & - & - & & \\
\hline クロツ & 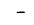 & - & 1 & - & - & - & - & - & - & - & & - \\
\hline 多力SP & - & - & $=$ & 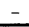 & - & - & - & - & - & - & 1 & \\
\hline 臌林性個体数 & 101 & 112 & 121 & 90 & 96 & 88 & 79 & 95 & 65 & 103 & 118 & 91 \\
\hline$\pi x x$ & 16 & 24 & 15 & 22 & 11 & 2 & 1 & 4 & 6 & 3 & 3 & 5 \\
\hline ホオジロ & 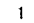 & 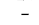 & 2 & 2 & 3 & 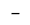 & 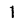 & i & & 1 & 4 & 3 \\
\hline カワラヒワ & 2 & 2 & 2 & 1 & - & - & 2 & 2 & - & 1 & 2 & 4 \\
\hline ハシプトガラス & - & 1 & 2 & 6 & 1 & - & 2 & 2 & 1 & - & & 2 \\
\hline ハシボソガラス & - & - & 2 & - & - & - & - & - & - & 1 & 2 & \\
\hline ッグミ & - & 1 & 3 & 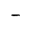 & 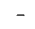 & - & - & - & - & 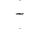 & - & - \\
\hline アカハラ & - & - & 2 & & - & - & - & - & - & 1 & - & - \\
\hline キジハト & - & 1 & - & - & - & 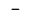 & - & - & - & 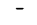 & - & 1 \\
\hline 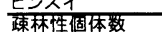 & 19 & $\frac{1}{30}$ & 28 & 31 & 15 & 2 & $\frac{-}{6}$ & $\frac{-}{9}$ & $\frac{-7}{7}$ & 7 & 11 & $\frac{-}{16}$ \\
\hline 総個体数 & 120 & 142 & 149 & 121 & $\frac{111}{111}$ & 90 & 85 & 104 & 72 & 110 & 129 & 107 \\
\hline 全種数 & 15 & 18 & 18 & 17 & 15 & 13 & 18 & 18 & 14 & 17 & 20 & 19 \\
\hline 低出現业 & 15 & 15 & 15 & 16 & 14 & 13 & 18 & 17 & 14 & 16 & 19 & 18 \\
\hline
\end{tabular}

（注）低出現頻度種除外とは、出現地区が2地区以下の喠を除外した種数（22種)て、この種数を重 回㷌分析や㮔組成の検討に用いた。

が発達していないため日照条件は良好であると考えられる。植物 種数の多さと植被率の高さ, 良好な日照条件によりこれらの地区 では昆虫相の種数・個体数の増加が考えられる。繁殖期には果実 食の種も昆虫を食べるようになり, 昆虫食の種が増加する。した がってこうした種に対して, 植物種数の多さと植被率の高さが, 昆虫の採食場所としての環境を多く提供するためプラスに働いた と考えられる。また林縁部という配置条件が, 樹林性鳥類の他に 疎林性鳥類に対しても有効に働いたことも要因と考えられる。実 際の調査区でも草本層の植被率が $90 \%$ と高いC区之G区は個体 数が 140 羽以上之他の地区よりもはるかに多い。本研究では草本 㸴の植被率が $70 \%$ 以上の地区, 特に $90 \%$ 以上の地区で個体数が 多い傾向が認められた。しかし草本層の植生密度が高くなるため には林木での照度が高いことが条件となる。これは低木層や亜高 木層が未発達であることを意味する。つまり低木層の薮を主に利 用するヤブサメやウグイスにとっては好ましくない環境となる。 実際にC区やG区ではウグイスもヤブサメ屯出現していない。鳥 の個体数を増やす意味では効果的ではあるが, 種組成を考慮する と草本層の発達が一概に望ましいとは言えない。このことは村井 ら (1988) ${ }^{1)}$ や一/瀬ら $(1996)^{5)}$ により低木層の発達が鳥類にとっ て重要であると示唆されていることからあ推察される。

個々の種について検討すると，まず特徴的な傾向を示した 5 種 について見ると, スズメとシメについて, 出現個体数の多かった $\mathrm{A} \cdot \mathrm{C} \cdot \mathrm{F} \cdot \mathrm{G} \cdot \mathrm{J}$ 区の共通点としては低木層の植被率が 15\% 以下と低いこと，また $\mathrm{A} ・ \mathrm{C} ・ \mathrm{G}$ 区では草本層の植被率が $70 \%$ 以上と非常に高いことがあげられる。スズメは農地や市街地を主 に生活の場としており ${ }^{11)}$, 比較的開放空間の多い疎生林を好んだ あのと考えられる。重回帰分析の結果加ら低木層の植被率の増 加は個体数の減少を引き起こす可能性が認められている。またシ メは明るい林を好み, 樹上や地上で採食することから ${ }^{11)}$, 草本層 の発達した環境に出現したものと考えられる。重回钼分析で得ら れた結果では, 草本層の植被率増加が正の相関関係にあることが 分かっている。アオジは疎林で薮の多いところを好むとされてい るが ${ }^{11)}$, 本研究では樹木密度が $1.00 \%$ 以上と高い B区之 L 区に 偏って出現しており, また重回帰分析の結果でも密度が正の相関 関係にある。この 2 地区は低木層の植被率も $40 \%$ と比較的高く, アオジは樹木密度が高い樹林の薮を好む可能性が考えられる。木 
トトギスについては重回帰分析からは樹林の高さと草本層の植被 率が関係しているという結果が得られたが，実際には托卵主であ るウグイスの出現場所に現れるあのと考えられる。ホトトギスの 生息環境はウグイスと一致しており薮のある林に生息するとされ ており ${ }^{11)}$ ，この特性を裏付ける結果だった。ジジュウカラは他の 地区に比べて $\mathrm{E} ・ \mathrm{I} ・ \mathrm{~K} ・ \mathrm{~L}$ 区で個体数が少なかった。本種は繁 殖期に林内の中・下層の繁みを採䭒場所として利用すると言われ ているが(12)13), 出現個体数が多かった地区は中・下層が開けた環 境であり，また亜高木層の植被率と負の相関関係にあった。この ような傾向が認められた原因については, 調査区周辺の環境条件 等の関係についても検討する必要があり, 本研究からは明らかに できなかった。

その他の相関が得られた種についても, 植生構造以外の要因が

影響している可能性があり, 更に検討する必要がある。

一方，統計上有意でなかった種について検討すると，ウグイス では多く出現していた B・D・H・I・K区はH区を除いて低木 層の植被率が $40 \%$ 以上高い值を示している。この結果はウグ イスが低木層の薮を主に利用すること ${ }^{11)}$ と合致していると考えら れる。ヤブサメはD・H・I・J・L区に出現しており, D・I ・ L区は低木層が密である。ヤブサメもウグイスと同様に低木層の 薮を利用すること ${ }^{11)}$ と合致している。キビ夕キは薄暗い林を好み, 木がある程度大きくて樹冠の下に空間があり, 中層から下層があ る程度茂っている林内に生息するとされている ${ }^{11)}$ 。キビタキは当 調査地で繁殖をしているが, 出現しなかった 3 地区については, $\mathrm{D} \cdot \mathrm{K}$ 区は他の地区に比べると低木層で特にアオキの優占度が高 くなっており（被度・群度：4・4）, またH区では他の地区に 比べると樹林規模がやや小さかった。このような傾向を示した理 由については不明であった。ハシボソガラスは D・G・I・K区 に出現している。本種は農耕地を主な生息地としているが，今回 G区を除く 3 区が密生林であった。本種は当調查地周辺の屋敷林 などで繁殖が確認されているが, 公園内での営巣は未確認である。 そのため何故このような出現傾向を示したかは明らかにできなかっ た。その他の種については出現傾向に大きな差が認められず, 植 生構造の影響については不明であった。

\section{(2) 樹林タイプと鳥相の関係}

一ノ瀬(1999)は林床の明るい林分が草地性鳥類にとって重要な 生息地となりうることを示している ${ }^{6)}$ 。タイプ I は草本層の植被 率が $70 \%$ 以上非常に高い值を示しており，林縁部に位置して いる。重回㷌分析の結果から，草本層の植被率之鳥の個体数は相 関関係にあり，実際の出現個体数も多かった。また種組成を見る 之, 疎林性鳥類も多く出現していた。本研究では一ノ瀬ら $(1999)^{6)}$ の結果を裏付けるとともに，林縁部の環境が鳥の個体数
増加にも寄与する可能性が示唆された。またタイプVは樹林の高 さがあり, 低木層が発達している。村井ら(1988) ${ }^{11}$ や一ノ瀬ら $(1996)^{5)}$ の結果と同様, こうした構造が種数の増加に貢献したも のと考えられる。加藤 $(1996)^{7)}$ は越冬期における調査により低木 層の植被率が $40 \%$

以上に增えても種の多様化には貢献しない可能性を指摘している。 本研究では低木層の植被率が 70\%・55\% と高い地区が 19 種・18 種と他の地区に比べ多かった。また個々の種の出現傾向から見る 之低木層の植被率が $40 \%$ を超えても種数が多い傾向を示してい た（表－2）。本研究は繁殖期を対象にしたものであり，繁殖期 においては低木層の植被率が $40 \%$ 以上であっても種の多様化に 貢献する可能性が示唆された。

前述の植生構造の相違と鳥相を比較すると, タイプごとに種数 が同じでも鳥の種組成が異なることが分かった（表一2）。特に 樹林性鳥類では種組成に顕著な違いが認められた。そのため複数 の樹林タイプが存在することで地域全体の鳥種の組成が多様化す ることが示唆される。

\section{5.まとめ}

以上のことから, 個々の種によって選好する環境が異なり, 本 研究においても複数の植生構造が鳥類の種多様化に必要であるこ とが示唆された。また既往の研究では低木層に注目して議論され ていたが, 本研究では草本層の在り方が影響することを明らかに した。このことは樹林性・疎林性どちらの鳥種に対しても当ては まった。樹林内で草本層の植被率を増加させることは, 鳥類の個 体数を増加させること, また踈林性鳥類を生息させるために効果 的であった。草本層の発達の目安として本研究では植被率が $70 \%$ 以上の地区，特に $90 \%$ の地区で個体数が多い傾向が認められた。

低木層の発達が種の多様化に寄与していることについては, 本 研究においても同様の結果が得られた。また繁殖期においては低 木層の植被率が高いほど鳥種の多様化を促す可能性が認められた。 また樹林タイプごとに種組成が異なる点も明らかにされた。従って 樹林を複数のタイプ用意することが重要であることが示唆された。

\section{謝辞}

本研究をまとめるにあたり, 日本大学生物資源科学部緑地・環 境計画学研究室の勝野武彦教授, 藤崎健一郎専任講師に助言を頂 き, 神奈川県土木事務所, 公園管理事務所の方々に便宜を図って いただいた。また植生調査は日本大学生物資源科学部緑地・環境 計画学研究室, 造園学研究室の学生に協力をしていただいた。こ の場を借りて御礼を申し上げる。
参考文献

1) 村井英紀・樋口広芳（1988）：森林性烏類の 多様性に影響する諸要因 : Strix 7, 83-100

2 ) 葉山嘉一(1994): 都市緑地における鳥類の 生息特性に関する研究 : 造園雑誌 57 (5), $229-234$

3 ) 葉山嘉一・高橋理喜男・勝野武彦 (1996) 都立東大和公園における植生と鳥類の生息 特性に関する研究：ランドスケープ研究 59 (5), 89-92

$4 ）$ 一/瀬友博 - 加藤和弘 (1994) : 埼玉県所沢 市の孤立樹林地における鳥類群集の分布に 影響を及ぼす諸要因について：造園雑誌 57 (5), $235-240$
5 ）一八瀬友博 - 加藤和弘（1996）：埼玉県所沢 市の孤立樹林地における越冬期の鳥類分布 と植生構造との関係について : ランドスケー プ研究 59 (5), 73-76

6 ）一八瀬友博 - 加藤和弘（1999）：武蔵野台地 および狭山丘陵の樹林地における鳥類分布 之植生の種組成の関係について：ランドス ケープ研究 62 (5), $577-580$

7 ) 加藤和弘 (1996): 都市緑地内の樹林地にお ける越冬期の鳥類と植生の構造の関係 : ラ ンドスケープ研究 59 (5), 77-80

8 ）大迫義人 (1989)：鳥類相調查における捕獲 ラインセンサスと定点観察の特性 : Strix 8, $179-186$
9 ) 生態学実習懇談会（1980）: 生態学実習書 : 朝倉書店, 336pp

10）由井正敏（1988）：森に棲む野鳥の生態学 : 創文, $237 \mathrm{pp}$

11）中村登流・中村雅彦（1995）: 原色日本野鳥 生態図鑑〈陸鳥編〉: 保育社, $301 \mathrm{pp}$

12）小笠原 (1970): 東北大学植物園におけるシ ジュウカラ科鳥類の混合群の解析 II : 山階 鳥研報 $6(1 / 2), 170-180$

13）中村登流 (1970): 日本における力ラ類群集 構造の研究 II : 山階鳥研報 6(1/2), $141-169$

Summary : The purposes of this study was to clarify the influence of vegetation structure on avifauna during the breeding season in Nanasawa forest park (64.6ha) located in the suburbs of Tanzawa,Kanagawa Prefecture. The investigation, was done on vegetation and avifauna at twelve different study sites. Avifauna was censused during the breeding season in 1999. For vegetation investigation we examined the woods structure, especially layer structure.

As a results, we concluded that the grass layers influence increased the number of birds. Also that avifauna was differed by the difference in vegetation structure. Avifauna's diversity was under the influence of the shrub layer density and the relationship between the vegetation structure. 